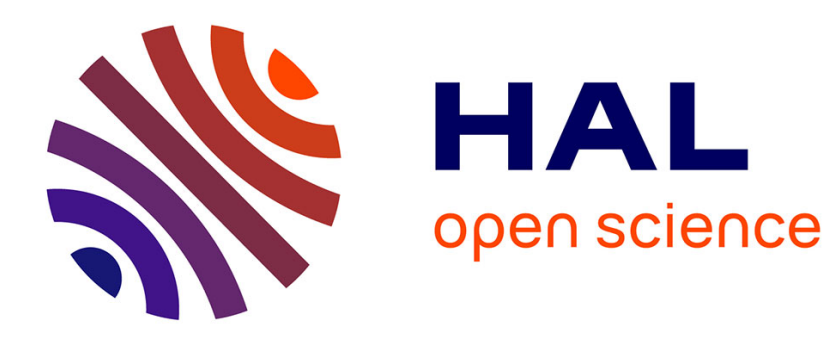

\title{
On the amorphous silicon on crystalline silicon heterojunctions
}

\author{
M. El-Raey, A. Abou-Aly
}

\section{To cite this version:}

M. El-Raey, A. Abou-Aly. On the amorphous silicon on crystalline silicon heterojunctions. Revue de Physique Appliquée, 1981, 16 (2), pp.35-36. 10.1051/rphysap:0198100160203500 jpa-00244896

\section{HAL Id: jpa-00244896 https://hal.science/jpa-00244896}

Submitted on 1 Jan 1981

HAL is a multi-disciplinary open access archive for the deposit and dissemination of scientific research documents, whether they are published or not. The documents may come from teaching and research institutions in France or abroad, or from public or private research centers.
L'archive ouverte pluridisciplinaire HAL, est destinée au dépôt et à la diffusion de documents scientifiques de niveau recherche, publiés ou non, émanant des établissements d'enseignement et de recherche français ou étrangers, des laboratoires publics ou privés. 


\title{
On the amorphous silicon on crystalline silicon heterojunctions
}

\author{
M. El-Raey and A. Abou-Aly \\ Department of Physics and Postgraduate Science Center, University of Alexandria, Alexandria, Egypt \\ (Reçu le 21 juillet 1980, réviséle 20 octobre 1980, acceptéle 23 octobre 1980)
}

\begin{abstract}
Résumé. - Une analyse précise et une meilleure interprétation de résultats récents sur les hétérojonctions a- $\mathrm{Si}$ donnent une consistance nouvelle aux mesures électriques et spectrales. Les résultats obtenus sur des barrières Schottky et la dispersion Mott-Schottky sont discutés.
\end{abstract}

\begin{abstract}
Accurate analysis and reinterpretation of recent results of a-Si heterojunctions have removed inconsistency of spectral and electrical measurements. Results of Schottky barriers and Mott-Schottky dispersion are discussed.
\end{abstract}

Recent interest in amorphous silicon solar cells has stimulated many workers to fabricate, measure and analyse their characteristics. A recently published work [1] has treated this subject. In that work, a junction was grown by d.c. sputtering of n-type silicon on a p-type crystalline substrate. Ohmic contacts were deposited by evaporation of aluminum. The junction obeyed Schottky model, both under forward and reverse bias conditions, but with higher idealization factor " $n$ " due to its high internal resistance. The authors interpreted their $1 / C^{2}-V$ relation as being due to the presence of localized and interface states. Their observed photovoltaic effect gave an efficiency of $0.25 \%$ and a fill factor of 0.26 due to high internal resistance. Analysis of normalized photoresponse gave a barrier height of $1.7 \mathrm{eV}$, while calculations from temperature dependence of $V-I$ characteristic curves gave a value of $0.09 \mathrm{eV}$, which is too low compared with that obtained from spectral response. The purpose of this article is to point out, and comment on, some of the misinterpretations of such work.

Apart from fabrication handicaps, which resulted in an a-Si layer of $0.12 \mu$ thickness, high internal resistance and an apparent interfacial $\mathrm{SiO}_{x}$ layer, the following comments have to be taken into consideration :

1) In view of the admitted high series resistance, the $I-V$ characteristic curve should have been compared to the general equation $[2,3]$

$I=I_{0}\left[\exp \left(\frac{-q\left(V-I R_{\mathrm{s}}\right)}{n K T}\right)-1\right]+\frac{V-I R_{\mathrm{s}}}{R_{\mathrm{sh}}}-I_{\mathrm{L}}$ rather than to $I=A \mathrm{e}^{-q V / n K T}$, which takes no account of the high series resistance $R_{\mathrm{s}}$ and leakage shunt resistance $R_{\mathrm{sh}}$ of the grown amorphous silicon. The physical process responsible for such a large value of idealization factor « $n$ » lies in the presence of a thick insulating $\mathrm{SiO}_{x}$ layer at the interface. This layer has pushed $V_{\text {oc }}$ to higher values, yielding poor fill factor and low photovoltaic conversion efficiency $[4,5]$.

2) The $V-I$ characteristic curve often exhibits a double exponential character, with the result that the idealization factor " $n$ " obtained at high voltages is nearly twice as much as that obtained at low voltages. In other words, lower slopes of the $V$-ln $(I)$ curve are obtained at higher voltages. However, the conclusion of [1] is inconsistent with this result and requires correction.

3) The inconsistency of barrier height obtained from the spectral response, as compared to that obtained from the temperature dependence of saturation current density $I_{0}$, is a result of fitting to the thermionic equation $I_{0}=A T^{2} \mathrm{e}^{-\varphi / K T}$. Rather, the temperature dependence of saturation density for such a nonideal Schottky barrier should be fitted to [6] :

$$
J=A^{* *} T^{2} \mathrm{e}^{-\varphi / n K T} .
$$

Where $A^{* *}$ is an effective Rishardson constant. The value of the barrier height of $0.09 \mathrm{eV}$ obtained in [1] should, therefore, be multiplied by their idealization $n \approx 20$ which yields the correct barrier height of $1.8 \mathrm{eV}$ in agreement with the result obtained from the spectral response. 
4) The dispersion observed in capacitance in the Mott-Schottky plot, cannot be attributed to surface states because surface states would contribute to the capacitance over only a relatively limited potential range i.e. a few tenths of a volt. The linear $I / C^{2}-V$ relation, indicates, that the surface states do not contribute appreciably to the observed capacity over potential range of interest. The change of the slope indicates the presence of two deep donor levels of different densities [7].

\section{References}

[1] Aboul-Seoud, K. and Mokhtar, O., Revue Phys. Appl. 13 (1978) 6413.

[2] Mallate, L. A. and Phillips, R. L., Appl. Opt. 11 (1978) 1786.

[3] Shirland, F. A., Adv. Energy Convers. 6 (1966) 201.

[4] Mizrah, T. and Adler, D., IEEE Trans. ED" 24 (1977) 458.

[5] Thompson, W. G., Stephen, I. F., ANDerson, R. L., WinN, O. H., IEEE Trans. ED 24 (1977) 463.

[6] NAville, R. C., Solar energy conversion : the solar cell (Elsevier) 1978, p. 198.

[7] Chai, Y., Anderson, W. and Anderson, L., IEEE, Trans. ED 24 (1977) 492. 